\title{
Phylogeography and Genotype-Symptom Associations in Early and Late Season Infections of Canola by Sclerotinia sclerotiorum
}

\author{
D. V. Phillips, I. Carbone, S. E. Gold, and L. M. Kohn
}

First author: Department of Plant Pathology, University of Georgia, Griffin Campus, Griffin 30223; second and fourth authors: Department of Botany, University of Toronto at Mississauga, ON Canada L5L 1C6; and third author: Department of Plant Pathology, University of Georgia, Athens 30602.

Accepted for publication 19 March 2002.

\begin{abstract}
Phillips, D. V., Carbone, I., Gold, S. E., and Kohn, L. M. 2002. Phylogeography and genotype-symptom associations in early and late season infections of canola by Sclerotinia sclerotiorum. Phytopathology 92:785793.

Both typical late season stem infections and atypical early season rosette infections of canola, a relatively new crop in the southeastern United States, were caused by Sclerotinia sclerotiorum. The 51 DNA fingerprints (from 71 isolates) did not match any fingerprints from previous studies of canola or other crops. Single locus haplotypes from nuclear DNA sequences included 18 in the intergenic spacer (IGS) of the rRNA repeat, four in 44.11, six in translation elongation factor $1 \alpha$, three in calmodulin (CAL), and two in chitin synthase 1. Contingency permutation testing for associations of infection type with DNA fingerprint, single- or multilocus
\end{abstract}

ABSTRACT haplotype, or hierarchically nested clades based on single locus haplotypes found significant association of haplotype with mycelial compatibility group and DNA fingerprint for all loci except CAL. Significant association of IGS haplotypes with symptom type was detected in one pathogen population. Southeastern U.S. canola was infected by both recently evolved, geographically dispersed pathogen genotypes and older, indigenous genotypes (Carbone and Kohn, 2001. Mol. Ecol. 10:947-964). Indigenous haplotypes are infection-type generalists, and the most frequently isolated from rosette infections. In contrast, haplotypes from the most recently evolved, dispersed population were associated one-to-one with infection type, with only the most recently evolved haplotypes infecting rosettes.

Additional keywords: cladistic inference, genome size, multilocus sequence typing, nested haplotype networks.
Phylogeography is the study of spatial distributions of genealogical lineages (phylogenies), especially lineages within species and among closely related species (2). Genealogies are inferred by parsimony or distance methods (7) or by coalescent approaches that use population parameters such as effective size and generation time in simulations to find the most probable route among a sample of alleles to their most recent common ancestor (12). In phylogeographical studies, analysis of genomic regions (loci) provides several advantages over the study of a single locus (13). These include differentiation of the history of the organism from the history of a single genomic region, replication to provide more rigorous hypothesis testing, acquisition of more phylogenetically informative polymorphisms (alleles) (5), as well as independence from a priori taxonomic assumptions (13). Phylogenies based on variation in cytoplasmic and nuclear DNA have been the tools for inferring the history of geographical subdivision, distinguishing modern day, population-splitting processes such as gene flow from historical events such as fragmentation or range expansion. This insight into allelic relatedness and history is not possible with the established population genetic approaches to determination of population subdivision, such as $F$ statistics (30).

Among plant- and human-infecting fungi there are a growing number of phylogeographic studies based on phylogenies from multilocus DNA sequence data in studies of species delimitation (23), population splitting within a species (21), as well as the combination of phylogenetic and coalescent approaches to both population splitting and speciation (5). The goals of this study were twofold. The first was to confirm that Sclerotinia sclerotiorum

Corresponding author: L. M. Kohn; E-mail address: kohn@utm.utoronto.ca

Publication no. P-2002-0517-01R

(C) 2002 The American Phytopathological Society
(Lib.) de Bary was the causal agent of both atypical and typical types of infections of canola (Brassica napus L.), a crop newly introduced to the southeastern United States. The second and main goal was to apply the phylogeography of $S$. sclerotiorum populations determined in a recent study (5) to find the source, in terms of relative antiquity and geographical location, of pathogen genotypes associated with these infection types.

$S$. sclerotiorum is a haploid, filamentous ascomycete with persistent soilborne sclerotia, but no conidia, and seasonally produced apothecia. S. sclerotiorum is an important pathogen, reported from more than 400 native and agricultural plant species (3). In the present study, the isolates from characteristic infections of southeastern U.S. canola were first identified as S. sclerotiorum by restriction fragment length polymorphism (19) and then were characterized in three ways: DNA fingerprinting, mycelial compatibility grouping, and DNA sequence haplotyping. DNA fingerprinting was by means of Southern hybridization of restrictiondigested whole genomic DNA to a cloned probe containing a $4.5 \mathrm{~kb}$ repeated dispersed element of nuclear DNA from $S$. sclerotiorum (20). In the course of several studies $(10,15,20)$, the Kohn laboratory has archived DNA fingerprints from more than 3,000 isolates from canola, cabbage, and other crops. Fingerprints of isolates in the present study could be compared against this database. Mycelial compatibility grouping is done by pairwise inoculation, exploiting a type of vegetative compatibility system. Isolates belonging to one mycelial compatibility group (MCG) paired in any combination can grow together to form a confluent colony. When paired with isolates of other MCGs, they do not grow together to form one confluent colony, but instead produce a reaction line in the zone of interaction $(10,20)$. Based on empirical studies to date $(4,6,10,17,20)$, all isolates in an MCG have one fingerprint unique to the MCG, or have two or more fingerprints, all unique to that MCG, that differ from each other by one to five hybridizing 


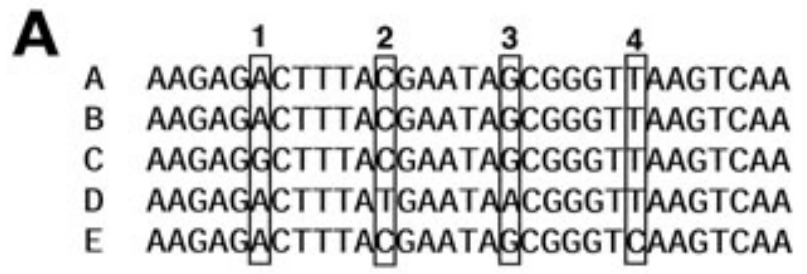
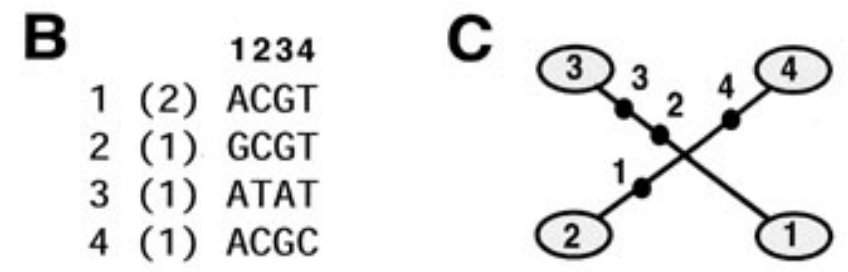

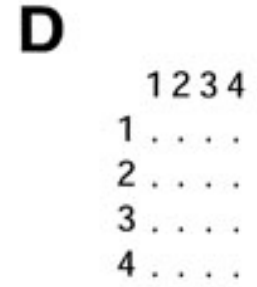

G

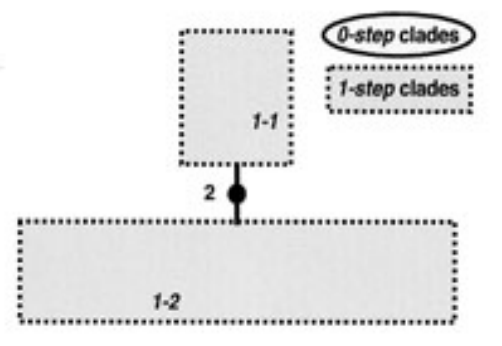

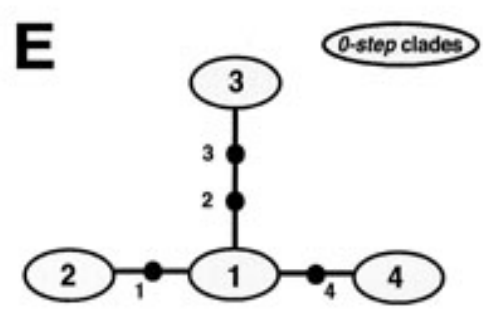

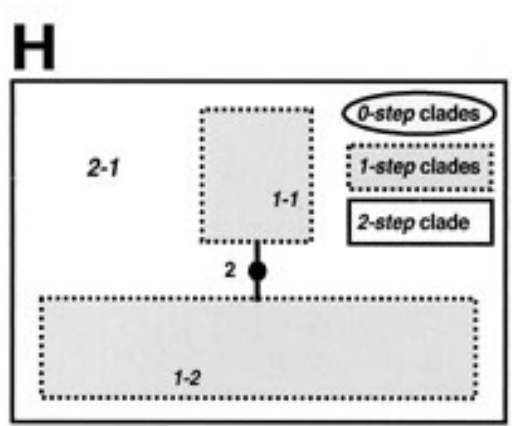

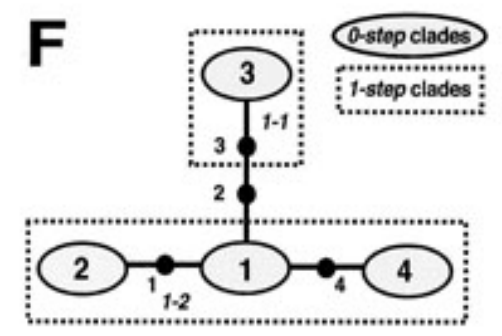
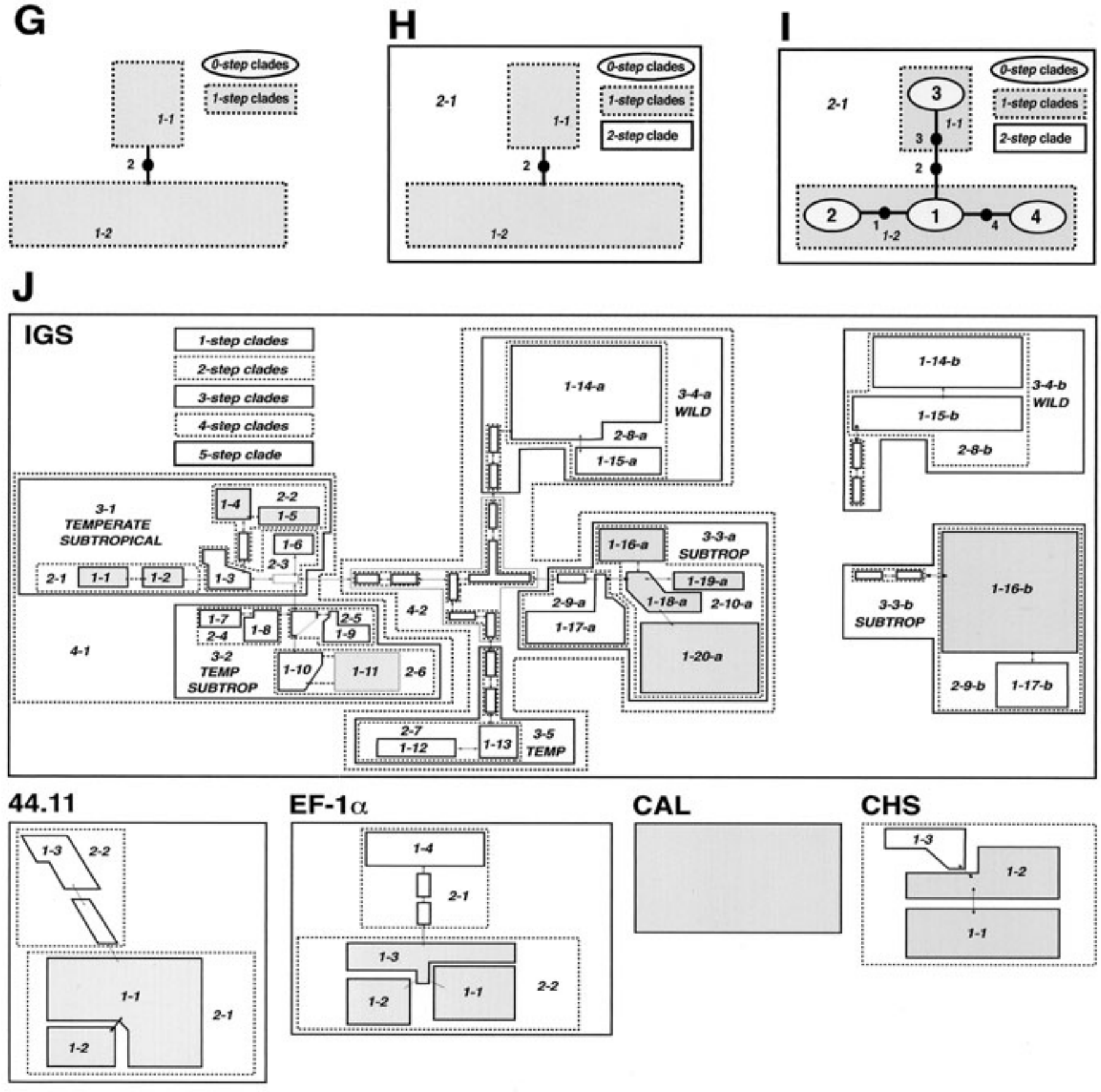

CAL

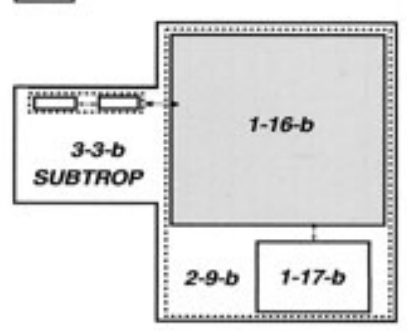


bands. Isolates from different MCGs have fingerprints that differ by more than five hybridizing bands.

DNA haplotyping of the isolates in the present study, and also those from other regions in North America and Europe, was part of a previous study (5). Haplotyping was based on DNA sequence data for seven loci: the intergenic spacer (IGS) region of the nuclear ribosomal RNA gene repeat unit (IGS; 4,000 bp), an anonymous nuclear region $(44.11 ; 700 \mathrm{bp})$, portions of the genes encoding translation elongation factor $1 \alpha(\mathrm{EF}-1 \alpha ; 350 \mathrm{bp})$, calmodulin (CAL; 500 bp), chitin synthase (CHS; 300 bp), actin (ACT; 300 bp), and ras protein (RAS; $350 \mathrm{bp}$ ). IGS size varied among isolates and is used as an independent category in the tests of association reported in this study. The haplotype was the basic unit for the phylogeographical analysis. Each isolate was assigned to a haplotype for each of the first five loci above; isolates of the same haplotype have the same nucleotides at polymorphic (variable) as well as at invariant positions of the locus (Fig. 1A and B). Each isolate was also assigned a multilocus haplotype (Table 1) based on all variable positions in all seven loci (5).

The haplotypes were used to determine a phylogeny from which the history and patterns of population splitting and population structure could be inferred (5). The basic steps are outlined from a simple, hypothetical example in Figure 1 and as follows: the most parsimonious unrooted tree is determined for the haplotypes (Fig. 1C); a compatibility matrix is constructed to detect conflict between the variable positions among the haplotypes that would result in the inference of many equally parsimonious trees rather than one (Fig. 1D); then, given that such conflict does not exist or is pruned from the data set, the phylogeny is converted into a network (Fig. 1E) which is then converted to a nested, hierarchical statistical design (Fig. 1F to I), with each nested level (clade) providing an independent variable for tests of association with geographical location or phenotypic characters such as symptom type. In the nested design, it is assumed that internal clades have more mutational derivatives (and are older) than tip clades. A key finding from the previous study was that there were four pathogen populations in North America (four of the five 3-step clades in the IGS network shown in Figure 1J), one of which, clade 3-3, was relatively old and endemic to the southeastern United States, whereas two others (clades 3-1 and 3-2) were more recently evolved and highly dispersed across North America. All four populations were associated with a variety of crops, including canola (5).

The first commercial crops of canola in Georgia were grown in the northern part of the state in the late 1980s. After planting, generally in October, plants bolt and begin flowering in late February or early March, with harvesting in June. Although both winter and spring canola cultivars can be grown successfully, winter cultivars generally produce higher yields. Sclerotinia stem rot was an immediate problem, with plant losses of over $30 \%$ observed frequently the first time canola was planted (24). S. sclerotiorum had not been a problem previously on other crops, although large acreage of a highly susceptible crop, such as winter canola, had not been grown in this region previously during the winter season.

In the early $1990 \mathrm{~s}$, canola production moved to southern Georgia and expanded into southern Alabama, northern Florida, and western South Carolina, where only spring-type cultivars are grown. It is usually planted in late October and early November, with flowering beginning in middle February and harvesting in May. The soils in this region generally have more sand and less clay and are not as easily saturated as those in northern Georgia. Although Sclerotinia stem rot is not consistently damaging, severe losses occur in wet years, particularly in poorly drained fields.

Symptoms include early, rosette stage infections typical of $S$. trifoliorum Eriks. on forage legumes but atypical of S. sclerotiorum on canola, as well as later-developing stem rot typical of $S$. sclerotiorum. In northern Georgia, most canola plants are killed by girdling stem lesions initiated during flowering, with basal stem infections occurring less frequently. Early-season infection of rosettes has been observed in December in some years, but usually not until January (24). In northern Georgia, rosette stage infections in December and January have preceded the observation of apothecia produced by $S$. sclerotiorum, but have coincided with peak ascospore production by $S$. trifoliorum $(26,33,34)$. In southern Georgia, apothecia of undetermined species affinity have been observed as early as December but are sometimes difficult to find later in the season during the flowering period (D.V. Phillips, unpublished data).

Alfalfa, clovers, and other legumes grown for forage or hay throughout these regions have been known for many years to be attacked by $S$. trifoliorum, particularly when planted in the autumn $(14,26,33,34)$. These legumes may also be attacked by $S$. sclerotiorum, and both species have been isolated from diseased plants (25). Although worldwide S. sclerotiorum is the species that usually causes stem rot on rapeseed and canola, in Europe, S. trifoliorum has been reported from the field and was pathogenic in greenhouse inoculations of rapeseed (29). S. trifoliorum has not been reported to be a naturally occurring pathogen of canola in North America. In the southeastern United States, rosette infections of canola could have been initiated either indirectly by ascospores of $S$. trifoliorum or directly from myceliogenically germinating sclerotia of $S$. sclerotiorum. Alternatively, S. sclerotiorum might have produced unobserved apothecia during the rosette stage of canola.

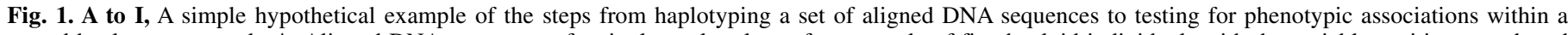

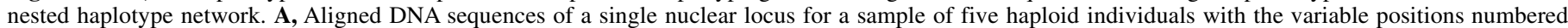

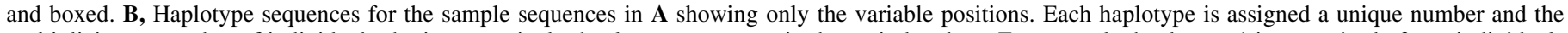

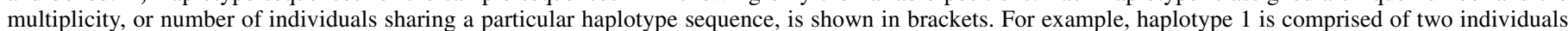

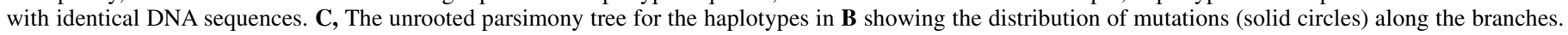

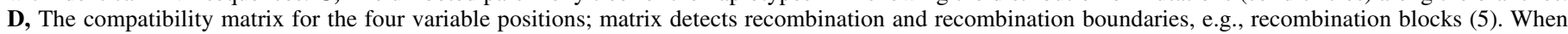

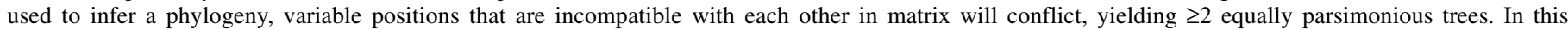

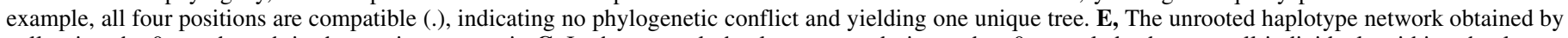

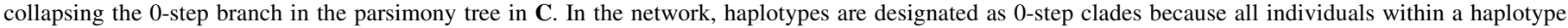

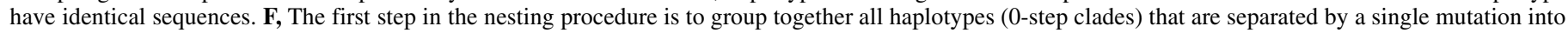

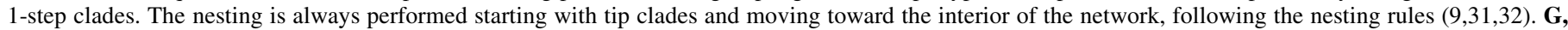

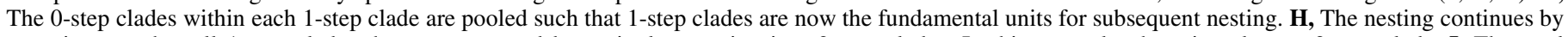

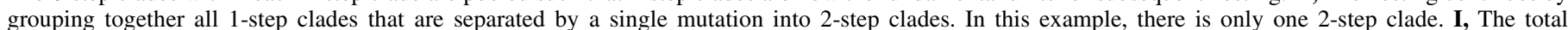

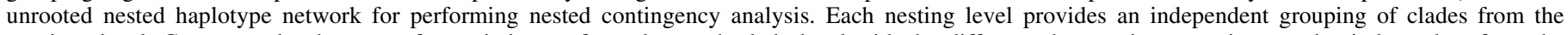

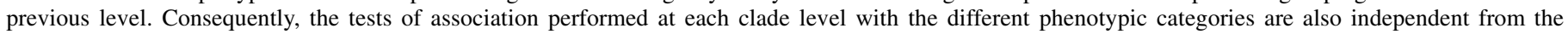

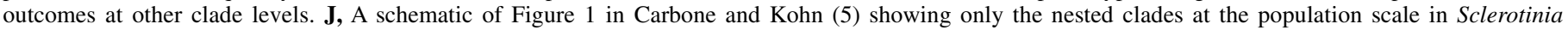

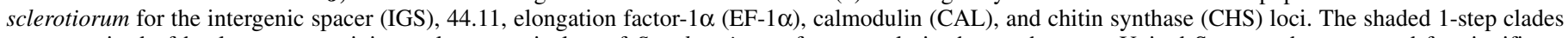

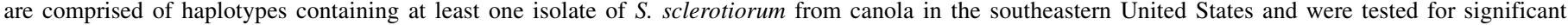

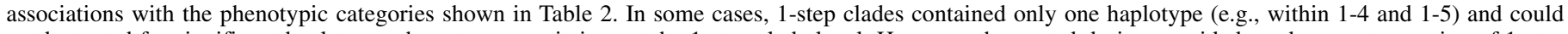

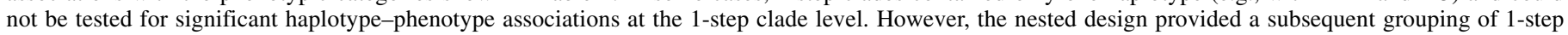
clades into 2-step clades such that tests of association could be performed at the 2-step clade level (e.g., within 2-2 for clades 1-4 and 1-5). 
In the present study, we determined whether the rosette infections were caused by $S$. sclerotiorum or $S$. trifoliorum. Given that $S$. sclerotiorum was the agent of infection, we determined whether there were any significant associations of rosette infections or basal or upper stem lesions with a set of variables representing different scales of genetic variation in the pathogen. These variables include the 0-step (haplotype), 1-step, 2-step, 3-step, and 4-step clades of nested phylogenetic networks for five genomic regions (loci), IGS sizes associated with each isolate, MCGs, and DNA fingerprint phenotypes. The three alternative hypotheses were that rosette infections were caused by $S$. trifoliorum, by genetic variants of $S$. sclerotiorum indigenous to the area, or by genetic variants of $S$. sclerotiorum introduced to the area.

\section{MATERIALS AND METHODS}

Isolates. A list of isolates and supporting information is provided in Table 1. Sixty-five of the seventy-one isolates were collected in 1997, with an additional six isolates from previous seasons. In 1997, the objective was to sample pathogen diversity in the region and to obtain isolates from plants with common symptoms (stem lesions) and unusual symptoms (rosette infections) from the same field. The target region was the southeastern United States where canola was introduced in the past 10 to
20 years. In 1997, lesions on leaves or crowns of plants in the rosette stage were sampled from 18 fields of canola from 28 January to 7 February. Stem lesions were sampled after bolting, from the same fields and 12 additional fields, from the middle of March through late April. Sampling included both basal stem lesions, in direct contact with the soil at the stem base, and upper stem lesions, at least $20 \mathrm{~cm}$ above the soil surface. Isolates were made from plant tissue excised from the lesion margin. One isolate was made per plant.

Species diagnosis. Whole genomic DNA was extracted from freeze-dried mycelium by disruption of cells with glass beads, followed by a phenol-chloroform extraction using the protocol of Kronstad and Leong (22). DNA was precipitated with polyethylene glycol (1) and digested to completion with EcoRI (Promega, Madison, WI). Approximately equal masses $(\approx 0.5 \mu \mathrm{g})$ were electrophoresed through $0.7 \%$ agarose gels in $0.5 \times$ Tris-borateEDTA (28) for $5 \mathrm{~h}$ at $1.5 \mathrm{~V} / \mathrm{cm}$. Southern blots were performed with a nonradioactive digoxigenin system according to manufacturer's instructions (DIG/Genius; Boehringer Mannheim Corp., Indianapolis, IN). The plasmid pMF2 containing the nuclear ribosomal repeat of Neurospora crassa (11) was used as the probe. Hybridization with this probe yields restriction length polymorphisms among Sclerotinia spp. (19). Three isolates were used as standards: LMK-211, the isolate of $S$. sclerotiorum used as a size

TABLE 1. Single and multilocus haplotypes, collection data, and phenotypic categories for 71 strains of Sclerotinia sclerotiorum from southeastern United States

\begin{tabular}{|c|c|c|c|c|c|c|c|c|c|c|c|c|c|c|c|}
\hline \multirow[b]{2}{*}{ Population } & \multirow[b]{2}{*}{ Strain $^{\mathrm{a}}$} & \multicolumn{6}{|c|}{ Haplotypes $^{b}$} & \multicolumn{5}{|c|}{ Phenotypic categories ${ }^{c}$} & \multirow[b]{2}{*}{ Locality } & \multirow[b]{2}{*}{ Field } & \multirow[b]{2}{*}{ Year } \\
\hline & & IGS & 44.11 & EF- $1 \alpha$ & CAL & CHS & $\begin{array}{l}\text { Multi- } \\
\text { locus }^{d}\end{array}$ & $\begin{array}{l}\text { IGS } \\
\text { size } \\
\text { (bp) }\end{array}$ & MCG & $\begin{array}{c}\text { DNA } \\
\text { fingerprint } \\
\text { designation }\end{array}$ & $\begin{array}{l}\text { Disease } \\
\text { symptom } \\
\text { type }\end{array}$ & Cultivar & & & \\
\hline \multirow[t]{13}{*}{$3-1$} & 847 & 36 & 4 & 2 & 3 & 3 & 105 & 4,043 & 39 & 1 & Upper stem & $?$ & Quincy, FL & EXP & 1997 \\
\hline & 849 & 25 & 4 & 6 & 3 & 2 & 107 & 4,045 & 7 & 2 & Upper stem & $\mathrm{L}$ & Arlington, GA & TSLF & 1997 \\
\hline & 856 & 25 & 4 & 6 & 3 & 2 & 107 & 4,045 & 7 & 2 & Base & $\mathrm{L}$ & Arlington, GA & TSSF & 1997 \\
\hline & 855 & 25 & 4 & 6 & 3 & 2 & 107 & 4,045 & 7 & 4 & Upper stem & $?$ & Tifton, GA & EXP 97 & 1997 \\
\hline & 861 & 25 & 3 & 2 & 3 & 2 & 64 & 4,045 & 42 & 5 & Upper stem & $?$ & Enterprise, AL & Curt & 1997 \\
\hline & 801 & 31 & 3 & 2 & 3 & 2 & 81 & 4,045 & 1 & 6 & Rosette & $\mathrm{L}$ & Calvary, GA & Field 2 & 1997 \\
\hline & 812 & 33 & 3 & 2 & 3 & 2 & 92 & 4,045 & 1 & 7 & Base & $\mathrm{L}$ & Blackville, SC & Cal & 1997 \\
\hline & 814 & 33 & 3 & 2 & 3 & 2 & 92 & 4,045 & 1 & 8 & Base & $\mathrm{L}$ & Dublin, GA & Malone & 1997 \\
\hline & 816 & 33 & 3 & 2 & 3 & 2 & 92 & 4,045 & 1 & 7 & Base & $?$ & Dexter, GA & Prod. Cen. & 1997 \\
\hline & 819 & 33 & 3 & 2 & 3 & 2 & 92 & 4,045 & 1 & 7 & Upper stem & $?$ & Midville, GA & BLN & 1997 \\
\hline & 827 & 33 & 3 & 2 & 3 & 2 & 92 & 4,045 & 1 & 7 & Base & $\mathrm{L}$ & Dexter, GA & Farm 1 & 1997 \\
\hline & 832 & 33 & 3 & 2 & 3 & 2 & 92 & 4,045 & 1 & 7 & Base & $\mathrm{L}$ & Summerdale, AL & Field 3 & 1997 \\
\hline & 857 & 33 & 3 & 2 & 3 & 2 & 92 & 4,045 & 1 & 7 & Upper stem & $\mathrm{L}$ & Arlington, GA & TSSF & 1997 \\
\hline \multirow[t]{19}{*}{$3-2$} & 843 & 29 & 3 & 6 & 3 & 2 & 86 & 4,046 & 10 & 9 & Upper stem & $\mathrm{L}$ & Calvary, GA & Field 1 & 1997 \\
\hline & 853 & 29 & 3 & 6 & 3 & 2 & 86 & 4,046 & 10 & 9 & Upper stem & $?$ & Griffin, GA & B'soe 97 & 1997 \\
\hline & 808 & 29 & 4 & 6 & 3 & 3 & 78 & 4,046 & 24 & 10 & Rosette & $?$ & Dexter, GA & Prod. Cen. & 1997 \\
\hline & 817 & 29 & 3 & 6 & 3 & 2 & 86 & 4,046 & 26 & 11 & Upper stem & $?$ & Dexter, GA & Prod. Cen. & 1997 \\
\hline & 818 & 29 & 4 & 6 & 3 & 2 & 87 & 4,046 & 27 & 12 & Base & $?$ & Midville, GA & BLN & 1997 \\
\hline & 829 & 29 & 4 & 2 & 3 & 2 & 99 & 4,046 & 31 & 13 & Upper stem & $\mathrm{L}$ & Summerdale, AL & Field 1 & 1997 \\
\hline & 837 & 29 & 4 & 2 & 3 & 3 & 100 & 4,046 & 32 & 14 & Upper stem & $?$ & Bluffton, GA & BLN & 1997 \\
\hline & 822 & 21 & 3 & 2 & 3 & 2 & 90 & 4,046 & 6 & 15 & Base & Oscar & Midville, GA & ST & 1997 \\
\hline & 848 & 21 & 3 & 2 & 3 & 2 & 90 & 4,046 & 6 & 15 & Base & $\mathrm{L}$ & Arlington, GA & TSLF & 1997 \\
\hline & 820 & 21 & 4 & 2 & 3 & 2 & 88 & 4,046 & 8 & 16 & Base & $\mathrm{L}$ & Santee, SC & $200 \mathrm{~A}$ & 1997 \\
\hline & 854 & 21 & 4 & 2 & 3 & 2 & 88 & 4,046 & 8 & 16 & Base & $?$ & Tifton, GA & EXP 97 & 1997 \\
\hline & 689 & 21 & 5 & 1 & 3 & 3 & 79 & 4,046 & 12 & 17 & Upper stem & Delta & Griffin, GA & CAN 1991 & 1991 \\
\hline & 821 & 21 & 4 & 6 & 4 & 3 & 89 & 4,046 & 28 & 18 & Upper stem & $\mathrm{L}$ & Santee, SC & $200 \mathrm{~A}$ & 1997 \\
\hline & 840 & 21 & 4 & 1 & 3 & 2 & 101 & 4,046 & 35 & 19 & Base & $\mathrm{L}$ & Summerdale, AL & Field 4 & 1997 \\
\hline & 724 & $21-1$ & 3 & 2 & 3 & 3 & 76 & 4,121 & 13 & 20 & Rosette & $?$ & Floyd Co., GA & EXP 92 & 1992 \\
\hline & 795 & $21-1$ & 4 & 1 & 3 & 3 & 77 & 4,121 & 15 & 21 & Rosette & G96-200E & Midville, GA & BUB & 1997 \\
\hline & 810 & $21-2$ & 3 & 2 & 3 & 2 & $90-1$ & 4,046 & 6 & 22 & Upper stem & G96-200E & Midville, GA & BUB & 1997 \\
\hline & 727 & 30 & 4 & 2 & 3 & 2 & 80 & 4,046 & 8 & 23 & Apothecium & - & Floyd Co., GA & EXP 92 & 1992 \\
\hline & & & & & & & & & & & & & \multicolumn{3}{|c|}{ (continued on next page $)$} \\
\hline
\end{tabular}

a Strain 689 was isolated from a canola plant (cv. Delta) growing in a microplot infested with sclerotia from a Canadian isolate and the native Georgia population.

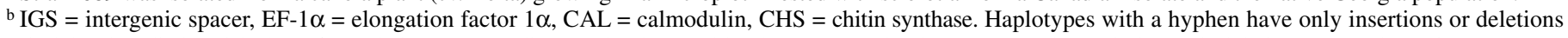
(indels) that distinguish them from their corresponding nonhyphenated haplotypes. For haplotype $21-2$, the variation at indel sites 873 and 881 is compensatory and there is no overall increase in IGS size.

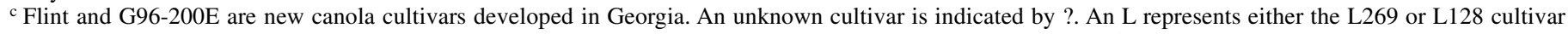
grown under contract with Calgene. Some fields had both cultivars and it is possible that isolates from the same field could be from different cultivars. MCG = mycelial compatibility group.

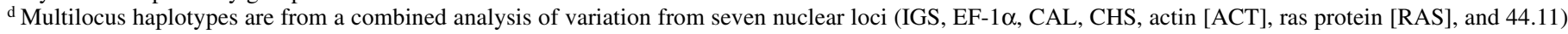
examined in Carbone and Kohn (5). 
standard on all Southern blots in the Kohn laboratory $(10,15,20)$, LMK-36, S. trifoliorum (19) and LMK-45, S. minor (19). Photographic images were compiled with the software application Photoshop 4.0 (Adobe Systems Inc., Mountain View, CA) and printed with a dye sublimation printer (Sony UP-D700; Sony, Cypress, CA) with Power Macintosh (Apple Computer Inc., Cupertino, CA) text editing.

Mycelial compatibility grouping and DNA fingerprinting. Mycelial compatibility grouping was performed in all combinations as previously described (20). Strains were paired on modified Patterson's medium (MPM) amended with 6 drops of red food coloring (McCormack Corp., Dallas) per liter. Each isolate was grown on MPM for 7 days before pairing. For pairing, 2-mm blocks of mycelial inoculum was removed from the inner colony ( $>1 \mathrm{~cm}$ from the growing margin) and placed $3.5 \mathrm{~cm}$ apart from the challenging isolate on MPM in a 9-cm petri dish, one pairing per dish, and incubated in the dark at room temperature. Pairings were scored after 7 days. Pairings were scored as incompatible when a red reaction line was observed on the colony reverse, or when the two isolates failed to grow together.

DNA extraction for fingerprinting and scoring of fingerprints was as described previously $(15,20)$. Whole cell genomic DNAs digested with BamHI were hybridized to a cloned probe, pLK 44.20 , containing a $4.5-\mathrm{kb}$ dispersed element of nuclear DNA from $S$. sclerotiorum (20). This probe hybridizes to approximately 4 to 25 Bam HI fragments, ranging in size from 2.2 to approxi- mately $25 \mathrm{~kb}$ in each isolate. One fingerprint pattern was used as a size standard (17), and DNA from one isolate with this fingerprint pattern was included in at least two lanes of each gel. Fragments were binned in 53 size classes, such that for each isolate, each of the 53 size classes was scored as present or absent (15).

Statistical analysis. DNA sequencing, organization of sequence data for the sample into haplotypes, and phylogenetic analysis of this sample was performed as part of a larger study (5). As in population-level analysis in the previous, larger study (5), the present study was based on nucleotide sequence polymorphisms in five nuclear loci: IGS, 44.11, EF-1 $\alpha, \mathrm{CAL}$, and CHS with two additional loci, ACT and RAS, included in the multilocus haplotypes, but not in the hierarchical nesting of single locus haplotypes. All sequences and multiple alignments have been accessioned in GenBank (AF340283 to AF342669). Significance of associations for hierarchically nested haplotypes at all five loci with IGS size, MCG, DNA fingerprint, and symptom type was assessed by performing 1,000 random, two-way, contingency permutations using the algorithm of Roff and Bentzen (27), implemented in CHIPERM version 1.2 (D. Posada, Brigham Young University, Provo, UT).

\section{RESULTS}

Species diagnosis. All 71 isolates were diagnosed as S. sclerotiorum based on comparison with standards for S. sclerotiorum, $S$.

TABLE 1. (continued from preceding page)

\begin{tabular}{|c|c|c|c|c|c|c|c|c|c|c|c|c|c|c|c|}
\hline \multirow[b]{2}{*}{ Population } & \multirow[b]{2}{*}{ Strain $^{\mathrm{a}}$} & \multicolumn{6}{|c|}{ Haplotypes ${ }^{\mathrm{b}}$} & \multicolumn{5}{|c|}{ Phenotypic categories $^{c}$} & \multirow[b]{2}{*}{ Locality } & \multirow[b]{2}{*}{ Field } & \multirow[b]{2}{*}{ Year } \\
\hline & & IGS & 44.11 & EF-1 $\alpha$ & CAL & CHS & $\begin{array}{l}\text { Multi- } \\
\text { locus }^{\text {d }}\end{array}$ & $\begin{array}{l}\text { IGS } \\
\text { size } \\
\text { (bp) }\end{array}$ & MCG & $\begin{array}{c}\text { DNA } \\
\text { fingerprint } \\
\text { designation }\end{array}$ & $\begin{array}{c}\text { Disease } \\
\text { symptom } \\
\text { type }\end{array}$ & Cultivar & & & \\
\hline \multirow[t]{40}{*}{$3-3$} & 803 & 15 & 3 & 6 & 3 & 2 & 66 & 3,901 & 2 & 24 & Rosette & Flint & Attapulgus, GA & EXP & 1997 \\
\hline & 833 & 15 & 3 & 6 & 3 & 2 & 66 & 3,901 & 2 & 24 & Upper stem & $\mathrm{L}$ & Summerdale, AL & Field 3 & 1997 \\
\hline & 831 & 15 & 3 & 6 & 3 & 2 & 66 & 3,901 & 2 & 25 & Upper stem & $\mathrm{L}$ & Summerdale, AL & Field 2 & 1997 \\
\hline & 680 & 15 & 7 & 6 & 3 & 3 & 65 & 3,901 & 3 & 26 & Upper stem & $?$ & Floyd Co., GA & EXP 90 & 1990 \\
\hline & 860 & 15 & 7 & 6 & 3 & 3 & 65 & 3,901 & 3 & 26 & Base & $?$ & Enterprise, AL & Curt & 1997 \\
\hline & 828 & 15 & 4 & 1 & 3 & 3 & 53 & 3,901 & 4 & 27 & Base & $\mathrm{L}$ & Summerdale, AL & Field 1 & 1997 \\
\hline & 842 & 15 & 4 & 1 & 3 & 3 & 53 & 3,901 & 4 & 28 & Base & $\mathrm{L}$ & Calvary, GA & Field 1 & 1997 \\
\hline & 823 & 15 & 3 & 6 & 3 & 2 & 66 & 3,901 & 5 & 29 & Upper stem & Oscar & Midville, GA & ST & 1997 \\
\hline & 804 & 15 & 3 & 5 & 3 & 2 & 67 & 3,901 & 20 & 30 & Rosette & $\mathrm{L}$ & Arlington, GA & TSSF & 1997 \\
\hline & 805 & 15 & 3 & 6 & 3 & 2 & 66 & 3,901 & 21 & 31 & Rosette & $?$ & Bluffton, GA & BLN & 1997 \\
\hline & 844 & 15 & 4 & 2 & 5 & 2 & 102 & 3,901 & 37 & 32 & Base & $\mathrm{L}$ & Calvary, GA & Field 2 & 1997 \\
\hline & 800 & 18 & 3 & 6 & 3 & 2 & 73 & 3,887 & 2 & 24 & Rosette & $\mathrm{L}$ & Calvary, GA & Field 1 & 1997 \\
\hline & 809 & 18 & 3 & 6 & 3 & 2 & 73 & 3,887 & 2 & 24 & Rosette & $?$ & Midville, GA & BLN & 1997 \\
\hline & 813 & 18 & 7 & 7 & 3 & 3 & 83 & 3,887 & 3 & 26 & Upper stem & $\mathrm{L}$ & Blackville, SC & Cal & 1997 \\
\hline & 834 & 18 & 7 & 6 & 3 & 3 & $83-1$ & 3,887 & 3 & 33 & Base & Flint & Attapulgus, GA & EXP & 1997 \\
\hline & 826 & 18 & 3 & 6 & 3 & 2 & 73 & 3,887 & 5 & 34 & Base & G96-200E & Midville, GA & BUB & 1997 \\
\hline & 811 & 18 & 3 & 6 & 3 & 2 & 73 & 3,887 & 5 & 29 & Rosette & Oscar & Midville, GA & ST & 1997 \\
\hline & 836 & 18 & 3 & 6 & 3 & 2 & 73 & 3,887 & 5 & 35 & Base & $?$ & Bluffton, GA & BLN & 1997 \\
\hline & 824 & 18 & 3 & 5 & 3 & 2 & 82 & 3,887 & 29 & 36 & Base & $\mathrm{L}$ & Orangeburg, SC & L269 & 1997 \\
\hline & 839 & 18 & 4 & 6 & 3 & 2 & 96 & 3,887 & 34 & 37 & Upper stem & $\mathrm{L}$ & Hartford, AL & NT & 1997 \\
\hline & 846 & 34 & 4 & 1 & 3 & 3 & 103 & 3,901 & 4 & 27 & Base & $?$ & Quincy, FL & EXP & 1997 \\
\hline & 798 & 19 & 3 & 6 & 3 & 2 & 71 & 4,029 & 17 & 38 & Rosette & $\mathrm{L}$ & Summerdale, AL & Field 2 & 1997 \\
\hline & 799 & 19 & 4 & 6 & 3 & 3 & 57 & 4,029 & 18 & 39 & Rosette & $\mathrm{L}$ & Summerdale, AL & Field 3 & 1997 \\
\hline & 802 & 19 & 3 & 6 & 3 & 2 & 71 & 4,029 & 19 & 40 & Rosette & $\mathrm{L}$ & Arlington, GA & TSLF & 1997 \\
\hline & 806 & 19 & 4 & 6 & 3 & 2 & 69 & 4,029 & 22 & 41 & Upper stem & $?$ & Plains, GA & EXP & 1997 \\
\hline & 807 & 19 & 4 & 2 & 3 & 3 & 70 & 4,029 & 23 & 42 & Rosette & $?$ & Plains, GA & EXP & 1997 \\
\hline & 830 & 26 & 3 & 6 & 3 & 2 & 93 & 3,901 & 2 & 24 & Base & $\mathrm{L}$ & Summerdale, AL & Field 2 & 1997 \\
\hline & 835 & 26 & 7 & 6 & 3 & 3 & 94 & 3,901 & 3 & 33 & Upper stem & Flint & Attapulgus, GA & EXP & 1997 \\
\hline & 728 & 26 & 4 & 1 & 3 & 3 & 68 & 3,901 & 4 & 27 & Rosette & $?$ & Griffin, GA & B'soe 92 & 1992 \\
\hline & 858 & 26 & 4 & 2 & 3 & 3 & 108 & 3,901 & 41 & 43 & Base & $?$ & Plains, GA & EXP & 1997 \\
\hline & 797 & 27 & 3 & 6 & 3 & 3 & 72 & 4,225 & 16 & 44 & Rosette & $\mathrm{L}$ & Summerdale, AL & Field 1 & 1997 \\
\hline & 815 & 27 & 3 & 3 & 3 & 2 & 84 & 4,225 & 25 & 45 & Upper stem & $\mathrm{L}$ & Dublin, GA & Malone & 1997 \\
\hline & 850 & 28 & 4 & 1 & 3 & 2 & 75 & 4,024 & 9 & 46 & Base & $?$ & Floyd Co., GA & EXP 97 & 1997 \\
\hline & 851 & 28 & 4 & 1 & 3 & 2 & 75 & 4,024 & 9 & 46 & Upper stem & $?$ & Floyd Co., GA & EXP 97 & 1997 \\
\hline & 729 & 28 & 4 & 3 & 3 & 2 & 74 & 4,024 & 14 & 47 & Rosette & $?$ & Tifton, GA & EXP 92 & 1992 \\
\hline & 838 & 28 & 4 & 1 & 3 & 3 & 97 & 4,024 & 33 & 48 & Base & $\mathrm{L}$ & Hartford, AL & NT & 1997 \\
\hline & 841 & 28 & 4 & 6 & 3 & 3 & 98 & 4,024 & 36 & 49 & Upper stem & $\mathrm{L}$ & Summerdale, AL & Field 4 & 1997 \\
\hline & 852 & 28 & 4 & 1 & 3 & 3 & 97 & 4,024 & 40 & 50 & Base & $?$ & Griffin, GA & B'soe 97 & 1997 \\
\hline & 825 & 32 & 3 & 1 & 3 & 3 & 85 & 4,024 & 30 & 51 & Upper stem & $\mathrm{L}$ & Orangeburg, SC & L269 & 1997 \\
\hline & 845 & 35 & 4 & 2 & 3 & 2 & 104 & 4,024 & 38 & 52 & Upper stem & $\mathrm{L}$ & Calvary, GA & Field 2 & 1997 \\
\hline
\end{tabular}


trifoliorum, and S. minor Jagger in Southern hybridizations of EcoRI-digested genomic DNA with cloned probe pMF2, containing the nuclear rRNA repeat of Neurospora crassa (Fig. 2). All of the test isolates had hybridizing fragments of 4.8, 3.9, and $2.2 \mathrm{~kb}$ as did the $S$. sclerotiorum standard (19). None of the test isolates had bands of $6.4 \mathrm{~kb}$ or greater, as were observed on the $S$. trifoliorum and S. minor standards (Fig. 2A). Some variation was observed in the size of the lowest molecular weight fragment when isolates 724,797 , and 815 were compared with the other test isolates and the standard (Fig. 2B). IGS length variation was observed, with these isolates falling into two haplotype groups (21-1 and 27) with the largest IGS sizes (Table 1). Culture morphology of all isolates and size of the ascospores in apothecia from which isolate 727 was made were consistent with those described for $S$. sclerotiorum (18).

Mycelial compatibility grouping and DNA fingerprinting. Forty-one MCGs were designated from the sample of 71 isolates (Table 1). Fifty-one DNA fingerprints were identified from this sample. Sample fingerprints are shown in Figure 3. Based on a distance analysis using the neighbor joining optimality criterion in phylogenetic analysis using parsimony (PAUP 4.0; D. L. Swofford, Smithsonian Institution, Washington, DC), there were no matches between fingerprints from this sample and samples from North Carolina cabbage (10), Louisiana cabbage (16), or Canadian canola $(15,17,20)$.

Statistical analysis. All results on populations of S. sclerotiorum were based on the nested haplotype networks from the larger previous study (5). In the present study, tests of association were performed at each nesting level to determine whether any significant association exists with haplotype and IGS size, MCG, DNA fingerprint, or disease symptom type (Table 2).

A significant association of haplotype with MCG and DNA fingerprint was observed at all loci, with the exception of CAL. Associations of all loci were more informative than the partial picture afforded by associations with each locus alone. Even a locus with very little sequence variation, for example CHS, corroborated the significant associations found in the IGS and other loci (Table 2).

Although fingerprints and MCGs were always associated, the association of haplotypes with fingerprint/MCG varied among loci. In the IGS region, with the exception of haplotype 33, haplo-

A

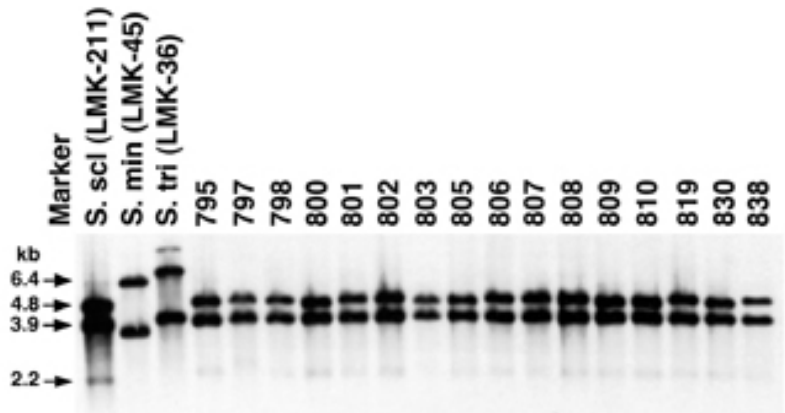

B

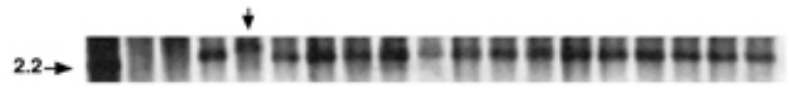

Fig. 2. Southern hybridization of EcoRI-digested DNA from Sclerotinia standard and canola isolates with the cloned probe pMF2 containing the nuclear ribosomal repeat of Neurospora crassa $(11,19)$. DNAs were HindIII-digested DNA (Marker), S. sclerotiorum standard isolate LMK-211 (S. scl), S. minor standard isolate LMK-45 (S. min), S. trifoliorum standard isolate LMK-36 (S. tri), and canola isolates as numbered and described in Table 1. A, Tenminute exposure showing all pertinent bands. B, Forty-minute exposure focusing on the 2.2-kb band region; arrow points to the restriction fragment length polymorphism in this band in isolate 797 relative to the standard and most other canola isolates. types were associated with more than one fingerprint/MCG. A similar pattern was observed at the other loci, with the only exception in 44.11 where haplotype 7 was associated exclusively with MCG3. Each IGS haplotype was associated with one pathogen population: 3-3, 3-2, or 3-1 (5). At the other loci, haplotypes were more frequently comprised of isolates from different populations (3-3, 3-1, and 3-2) or associated only with population 3-3 (haplotype 7 in 44.11; haplotypes 3, 5, and 7 in EF-1 $\alpha$ ). The differentiation of 3-3 from 3-1 and 3-2 at the other loci is consistent with the population structure observed in the IGS region (clades 4-1 and 42 in Figure 1 of Carbone and Kohn [5]) before the extensive fragmentation event inferred to have separated 3-3 from 3-1 and 3-2.

A significant association with disease symptom type was observed within population 3-2 based on IGS haplotypes. Within 3-2, haplotypes were significantly associated with upper stem infections (haplotype 29), basal infections (haplotype 21), or rosette infections (haplotype 21-1). Within populations 3-1 and 3-2, rosette stage infections were not as prevalent (Table 3 ) and were

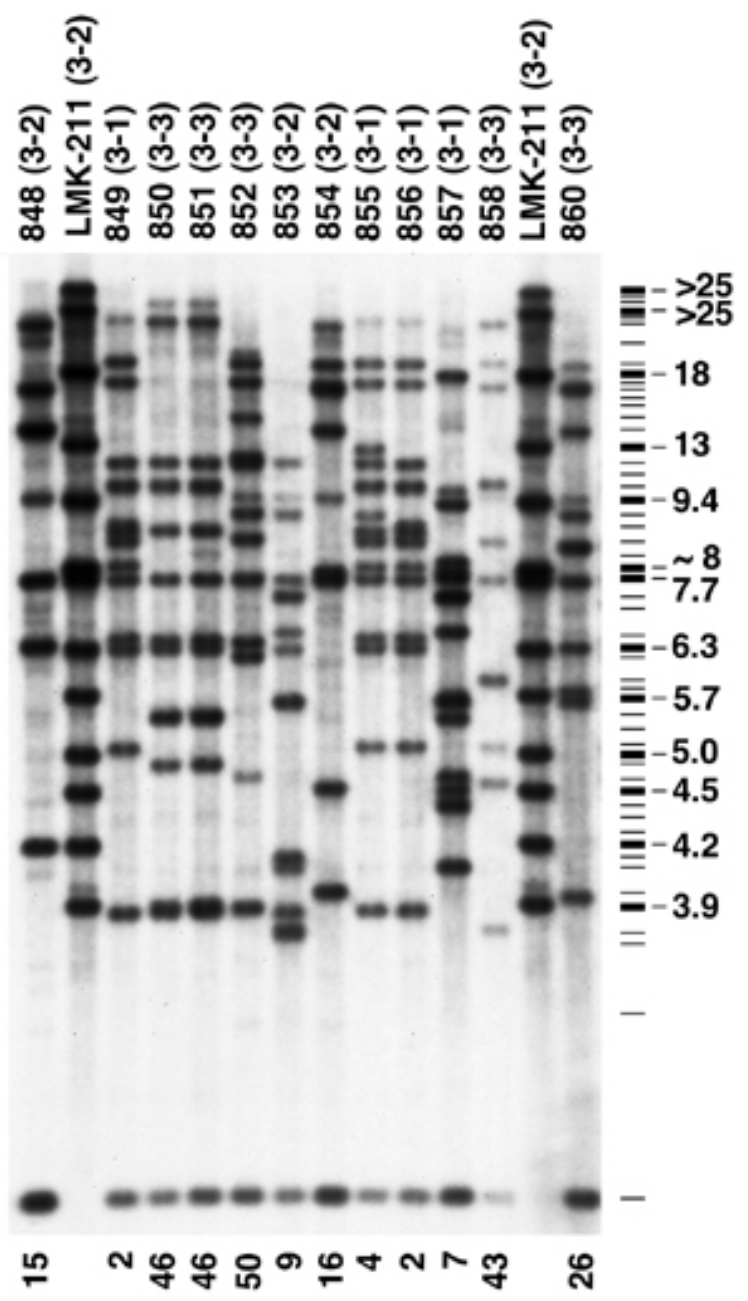

Fig. 3. Representative DNA fingerprints of Sclerotinia sclerotiorum from southeastern U.S. canola obtained by Southern hybridization of BamHI-digested genomic DNAs probed with the plasmid pLK 44.20, containing a dispersed repetitive element from S. sclerotiorum (20). The S. sclerotiorum population designation of each isolate is shown in brackets after the isolate number above the lanes, and fingerprint designations are shown below. Fingerprint designations refer only to isolates in the present study. Included is the $S$. sclerotiorum size standard (LMK-211) used as the reference isolate in all S. sclerotiorum fingerprinting studies. The molecular weights (in kilobases) of hybridizing bands in the fingerprint profile of LMK-211 (thick bars in the schematic fingerprint profile) are shown as presented previously (15); the additional bars in the schematic profile show the relative positions of all 53 possible bins of hybridizing fragments in S. sclerotiorum utilized in scoring. 
significantly associated with IGS haplotypes 31 and 21-1, which were among the most recently evolved haplotypes, i.e., located at the tips of the IGS haplotype network (5). The older, interior haplotypes in the network were significantly associated with stem infections. These haplotypes were associated with either base lesions $(20,32)$ or upper stem lesions $(24,28)$, but not with both. By comparison, no significant association of haplotype with disease symptom was detected in population 3-3. In this population, the more frequently recovered haplotypes $(14,17)$ were not significantly associated with any specific disease symptom and rosette stage infections were as frequent as upper stem and basal lesions (Table 3). A similar frequency distribution was observed with the less frequently recovered haplotypes, with the exception of haplotype 19, which was almost exclusively associated with rosette stage infections.

\section{DISCUSSION}

We determined unambiguously that all isolates sampled from southeastern U.S. canola were $S$. sclerotiorum, not $S$. trifoliorum. This was a requisite first step before extensive genotyping and sequencing could commence, especially bearing in mind that all species of Sclerotinia hybridize with the fingerprinting element (20), that they are morphologically very similar, and most importantly, that there was an initial question about whether $S$. trifoliorum, not $S$. sclerotiorum, was causing at least some infections sampled in this study. Variation in the size of the lowest molecular weight restriction fragment from isolates 724,797 , and 815 compared with the other test isolates and the standard was consistent with increased IGS size in these isolates. Increases in genome size due to expansions in the nuclear rDNA array within fungal populations may be a common phenomenon (6). Increase in IGS size through microsatellite expansion has been demonstrated within subpopulation 3-4 of S. sclerotiorum (6), as have increases in size variants of the rDNA array in experimental populations of Candida albicans (8).

Southeastern U.S. canola has been infected both by highly mobile, geographically dispersed pathogen genotypes and by indigenous, geographically localized genotypes. Of the 71 isolates, $57 \%$ (Table 3) represented the evolutionarily older population endemic to the southeastern United States (IGS clade 3-3 in Figure 1J). Furthermore, IGS haplotypes from clade 3-3 represent isolates that are infection-type generalists, causing more of the unusual rosette stage infections ( $76 \%$ of isolates from this symptom type) than isolates associated with haplotypes in populations 3-2 and 31 (Table 3). Whereas haplotypes from the most recently evolved, geographically dispersed population (IGS clade 3-2 in Figure 1J) showed a one-to-one association with infection type, with $18 \%$ from rosette infections, haplotypes from the other highly dispersed population (IGS clade 3-1 in Figure 1J) were associated mainly with stem infections (Table 3). It appears that the prevalence of rosette infections in the southeastern United States is mainly

TABLE 2. Results from nested contingency analysis of categorical associations with haplotypes at five nuclear loci in Sclerotinia sclerotiorum ${ }^{\mathrm{a}}$

\begin{tabular}{|c|c|c|c|c|c|c|c|c|c|c|}
\hline \multirow[b]{3}{*}{ Locus } & \multirow[b]{3}{*}{ Clade $^{b}$} & \multirow[b]{3}{*}{ Population } & \multicolumn{8}{|c|}{ Phenotypic categories $^{c}$} \\
\hline & & & \multicolumn{2}{|c|}{ IGS size } & \multicolumn{2}{|c|}{ MCG } & \multicolumn{2}{|c|}{ DNA fingerprint } & \multicolumn{2}{|c|}{ Disease symptom $^{\mathrm{d}}$} \\
\hline & & & $X^{2}$ & $P$ & $X^{2}$ & $P$ & $X^{2}$ & $P$ & $X^{2}$ & $P$ \\
\hline \multirow[t]{10}{*}{ IGS } & $1-11$ & $3-2$ & 18.00 & $0.010 *$ & 44.57 & 0.766 & 72.00 & $0.014 *$ & 16.60 & $0.005^{*}$ \\
\hline & $1-20-\mathrm{a}$ & $3-3$ & - & - & 7.82 & 0.926 & 14.06 & 0.914 & 0.96 & 1.000 \\
\hline & $1-16-b$ & $3-3$ & 1.84 & 0.797 & 24.21 & 0.479 & 25.96 & 0.680 & 1.02 & 1.000 \\
\hline & $2-10-\mathrm{a}$ & $3-3$ & 96.00 & $0.000 *$ & 77.76 & $0.001 *$ & 80.07 & $0.029^{*}$ & 6.91 & 0.355 \\
\hline & $2-1$ & $3-1$ & 5.00 & 0.200 & 5.00 & 0.423 & 5.00 & 1.000 & 0.31 & 1.000 \\
\hline & $2-2$ & $3-1$ & - & - & - & - & 8.00 & 0.234 & 8.00 & 0.136 \\
\hline & $3-1$ & $3-1$ & 1.73 & 0.392 & 13.00 & $0.001 *$ & 12.00 & $0.015^{*}$ & 3.85 & 0.163 \\
\hline & $3-3-a$ & $3-3$ & 40.00 & $0.000 *$ & 39.00 & $0.001 *$ & 39.00 & $0.003^{*}$ & 2.19 & 0.356 \\
\hline & $4-1$ & $3-1,3-2$ & 31.00 & $0.000 *$ & 31.00 & $0.000^{*}$ & 31.00 & $0.002 *$ & 0.77 & 0.791 \\
\hline & Total & $3-1,3-2,3-3$ & 71.00 & $0.000 *$ & 70.00 & $0.000 *$ & 70.00 & $0.000 *$ & 3.60 & 0.187 \\
\hline \multirow[t]{2}{*}{44.11} & $1-1$ & $3-1,3-2,3-3$ & 23.79 & 0.128 & 140.00 & $0.000^{*}$ & 139.00 & $0.000 *$ & 3.55 & 0.498 \\
\hline & Total & $3-1,3-2,3-3$ & 3.42 & 1.000 & 71.00 & $0.028 *$ & 7.43 & 1.000 & 1.62 & 1.000 \\
\hline \multirow[t]{3}{*}{$\mathrm{EF}-1 \alpha$} & $1-1$ & $3-1,3-2,3-3$ & 18.21 & $0.048 *$ & 25.00 & 0.089 & 24.00 & 0.139 & 2.55 & 0.492 \\
\hline & $1-2$ & $3-1,3-2,3-3$ & 4.67 & 0.961 & 39.92 & 0.468 & 33.23 & 0.936 & 2.96 & 0.687 \\
\hline & Total & $3-1,3-2,3-3$ & 42.85 & $0.000 *$ & 141.00 & $0.000 *$ & 143.00 & $0.000 *$ & 6.26 & 0.163 \\
\hline CAL & Total & $3-1,3-2,3-3$ & 6.95 & 1.000 & 141.00 & 0.106 & 141.00 & 0.232 & 3.30 & 0.875 \\
\hline CHS & Total & $3-1,3-2,3-3$ & 16.23 & $0.021 *$ & 71.00 & $0.000 *$ & 71.00 & $0.000 *$ & 0.51 & 0.764 \\
\hline
\end{tabular}

a Statistical significance was assessed by performing 1,000 random permutations of the original data matrix constructed such that the rows correspond to subclades and the columns to phenotypes. Each randomization was performed by permuting the original data matrix such that the row and column totals remained constant. A total of 1,000 randomizations of the original data matrix were used to generate the expected distributions of $X_{e}^{2}$; only the observed $X^{2}$ statistics are shown. $P$ is the estimated probability of obtaining a value of $X_{e}^{2} \geq X^{2}$ and was approximated using a Monte Carlo approach.

${ }^{\mathrm{b}}$ Clade designations are from Figure 1 in Carbone and Kohn (5).

c Phenotypic distributions for each category: nine intergenic spacer (IGS) size classes (3,887; 3,901; 4,024; 4,029; 4,043; 4,045; 4,046; 4,121; and 4,225 bp), 41 distinct mycelial compatibility groups (MCGs) (Table 1), 51 unique DNA fingerprints (Table 1), and three disease symptom-types (upper stem, basal stem, and rosette infection). - indicates no phenotypic variation within clade.

${ }^{\mathrm{d}}$ Strain 727 was excluded from association tests (unknown disease symptom-type). * indicates significant association at $P=0.05$.

TABLE 3. Distribution of disease-causing isolates from upper stem, basal stem, and rosette stage infections within populations 3-1, 3-2, and 3-3

\begin{tabular}{|c|c|c|c|c|}
\hline \multirow[b]{2}{*}{ Population $^{\mathrm{a}}$} & \multirow[b]{2}{*}{ Total number of strains $(\%)^{\mathrm{b}}$} & \multicolumn{3}{|c|}{ Disease isolates } \\
\hline & & Upper stem (\%) & Basal stem (\%) & Rosette $(\%)$ \\
\hline $3-1$ & $13(19)$ & $6(22)$ & $6(23)$ & $1(6)$ \\
\hline $3-2$ & $17(24)$ & $8(30)$ & $6(23)$ & $3(18)$ \\
\hline
\end{tabular}

${ }^{a}$ Strain 727 was excluded from population 3-2 (unknown disease-causing symptom).

${ }^{b}$ Parentheses indicate percentage of isolates in the total sample.

${ }^{c}$ Parentheses indicate percentage of isolates with a particular disease symptom-type in populations 3-1, 3-2, and 3-3. 
attributable to indigenous haplotypes and, to a lesser extent, to the most recently evolved haplotypes in the mobile, dispersed populations.

Because of the limitations of the sampling design, we view any associations of canola variety with symptom type associations as preliminary. The ideal sample would recover the pathogen from a set of canola varieties from a set of fields each infested with several haplotypes. Research to determine the influence of canola variety on the distribution of S. sclerotiorum genotypes is warranted.

Clonality predominates in this sample, evidenced by the association of DNA fingerprint with MCG $(4,20)$ among all loci except CAL, despite the history of recombination in the endemic population 3-3 (5). Recombination would shuffle determinants of fingerprint and MCG, which are unlikely to be physically linked, resulting in a lack of association between these two markers. Some isolates that were mycelially compatible had fingerprints that differed by one or two hybridizing bands, consistent with ongoing evolution of new fingerprints, most likely through transposition of the fingerprint element $(4,6)$. For example, isolates 855 and 856 both belong to MCG7, yet 855 has two additional hybridizing bands in its fingerprint profile (Fig. 3).

The predominance of isolates representing the old endemic population 3-3, and ability of these haplotypes to cause both the more usual stem infections and the unusual rosette infections, are consistent with a testable hypothesis. The hypothesis is that the observed high yield losses under conducive conditions as canola was introduced to the southeastern United States were due primarily to endemic pathogen genotypes adapted to many hosts, able to infect under a wide range of local conditions, and therefore able to cause both early and late season infections of canola. The genotypes representing the more recently evolved, geographically dispersed populations (3-1 and 3-2) may be more associated with canola and therefore the more typical late season stem infections. It is possible that these genotypes were introduced with canola to the region.

In this study, we compared several types of data, namely haplotypes for DNA sequences at seven genomic regions (loci), MCGs, DNA fingerprints, and canola symptom type by testing for significant associations in a nested statistical design based on five of the seven loci. This approach can be applied to many other associations in other pathosystems. Clearly, the multilocus approach is more powerful than reliance on one genomic region. Even loci with limited numbers of phylogenetically informative sites are useful because they strengthen the interpretation by either adding informative associations or by confirming associations observed from other loci. Rapidly increasing genomic databases are facilitating this kind of data exploration.

\section{ACKNOWLEDGMENTS}

This research was supported by a research grant to L. M. Kohn and a postgraduate scholarship to I. Carbone, both from the Natural Sciences and Engineering Research Council of Canada, and by a grant to D. V. Phillips from the USDA-CSREES Southeastern Canola Research Program.

\section{LITERATURE CITED}

1. Ausubel, F. M., Brent, R., Kingston, R. E., Moore, D. D., Seidman, J. G., Smith, J. A., and Struhl, K. 1998. Current Protocols in Molecular Biology. John Wiley \& Sons, New York.

2. Avise, J. C. 2000. Phylogeography: The History and Formation of Species. Harvard University Press, Cambridge, MA.

3. Boland, G. J., and Hall, R. 1994. Index of plant hosts of Sclerotinia sclerotiorum. Can. J. Plant Pathol. 16:93-108.

4. Carbone, I., Anderson, J. B., and Kohn, L. M. 1999. Patterns of descent in clonal lineages and their multilocus fingerprints are resolved with combined gene genealogies. Evolution 53:11-21.

5. Carbone, I., and Kohn, L. M. 2001. A microbial population-species interface: Nested cladistic and coalescent inference with multilocus data.
Mol. Ecol. 10:947-964.

6. Carbone, I, and Kohn, L. M. 2001. Multilocus nested haplotype networks extended with DNA fingerprints show common origin and fine-scale, ongoing genetic divergence in a wild microbial metapopulation. Mol. Ecol. 10:2409-2422.

7. Couch, B. C., and Kohn, L. M. 2000. Clonal spread of Sclerotium cepivorum in onion production with evidence of past recombination events. Phytopathology 90:514-521.

8. Cowen, L. E., Sanglard, D., Calabrese, D., Sirjusingh, C., Anderson, J. B., and Kohn, L. M. 2000. Evolution of drug resistance in experimental populations of Candida albicans. J. Bacteriol. 182:1515-1522.

9. Crandall, K. A. 1996. Multiple interspecies transmissions of human and simian T-cell leukemia/lymphoma virus type I sequences. Mol. Biol. Evol. 13:115-131.

10. Cubeta, M. A., Cody, B. R., Kohli, Y., and Kohn, L. M. 1997. Clonality in Sclerotinia sclerotiorum on infected cabbage in eastern North Carolina. Phytopathology 87:1000-1004.

11. Free, S. J., Rice, P. W., and Metzenberg, R. L. 1979. Arrangement of the genes coding for ribosomal ribonucleic acids in Neurospora crassa. J. Bacteriol. 137:1219-1226.

12. Griffiths, R. C., and Tavaré, S. 1994. Ancestral inference in population genetics. Stat. Sci. 9:307-319.

13. Hare, M. P. 2001. Prospects for nuclear gene phylogeography. Trends Ecol. Evol. 16:700-706.

14. Hoveland, C. S., Durham, R. G., and Bouton, J. H. 1996. No-till seeding of grazing-tolerant alfalfa as influenced by grass suppression, fungicide, and insecticide. J. Prod. Agric. 9:410-414.

15. Kohli, Y., Brunner, L. J., Yoell, H., Milgroom, M. G., Anderson, J. B., Morrall, R. A. A., and Kohn, L. M. 1995. Clonal dispersal and spatial mixing in populations of the plant pathogenic fungus, Sclerotinia sclerotiorum. Mol. Ecol. 4:69-77.

16. Kohli, Y., and Kohn, L. M. 1998. Random association among alleles in clonal populations of Sclerotinia sclerotiorum. Fungal Genet. Biol. 23:139-149.

17. Kohli, Y., Morrall, R. A. A., Anderson, J. B., and Kohn, L. M. 1992. Local and trans-Canadian clonal distribution of Sclerotinia sclerotiorum on canola. Phytopathology 82:875-880.

18. Kohn, L. M. 1979. A monographic revision of the genus Sclerotinia. Mycotaxon 9:365-444.

19. Kohn, L. M., Petsche, D. M., Bailey, S. R., Novak, L. A., and Anderson, J. B. 1988. Restriction fragment length polymorphisms in nuclear and mitochondrial DNA of Sclerotinia species. Phytopathology 78:10471051.

20. Kohn, L. M., Stasovski, E., Carbone, I., Royer, J., and Anderson, J. B. 1991. Mycelial incompatibility and molecular markers identify genetic variability in field populations of Sclerotinia sclerotiorum. Phytopathology 81:480-485.

21. Koufopanou, V., Burt, A., and Taylor, J. W. 1997. Concordance of gene genealogies reveals reproductive isolation in the pathogenic fungus $\mathrm{Coc}$ cidioides immitis. Proc. Natl. Acad. Sci. USA 94:5478-5482.

22. Kronstad, J. W., and Leong, S. A. 1989. Isolation of two alleles of the b locus of Ustilago maydis. Proc. Natl. Acad. Sci. USA 86:978-982.

23. O'Donnell, K., Cigelnik, E., and Nirenberg, H. I. 1998. Molecular systematics and phylogeography of the Gibberella fujikuroi species complex. Mycologia 90:465-493.

24. Phillips, D. V., and Raymer, P. L. 1995. The relationship between time of development of apothecia and appearance of symptoms of Sclerotinia stem rot in the southeastern USA. Pages 637-639 in: Proc. Int. Rapeseed Congr., 9th. Henry Ling, Ltd., Dorchester, UK.

25. Pratt, R. G., Dabney, S. M., and Mays, D. A. 1988. New forage legume hosts of Sclerotinia trifoliorum and S. sclerotiorum in the southeastern United States. Plant Dis. 72:593-596.

26. Pratt, R. G., and Knight, W. E. 1982. Formation of apothecia by Sclerotinia trifoliorum and infection of crimson clover in the field. Plant Dis. 68:1021-1023

27. Roff, D. A., and Bentzen, P. 1989. The statistical analysis of mitochondrial DNA polymorphisms: $\chi^{2}$ and the problem of small samples. Mol. Biol. Evol. 6:539-545.

28. Sambrook, J., Fritsch, E. F., and Maniatis, T. 1989. Molecular Cloning: A Laboratory Manual. 2nd ed. Cold Spring Harbor Laboratory, Cold Spring Harbor, NY.

29. Saur, R., and Locher, F. 1983. Die bestimmung des ascosporenfluges von Sclerotinia sclerotiorum (Lib.) de Bary als entscheidungshilfe fur die bekampfung von rapskrebs. Pages 891-896 in: Proc. Int. Rapeseed Conf., 6th. Paris, France.

30. Templeton, A. R. 1998. Nested clade analyses of phylogeographic data: Testing hypotheses about gene flow and population history. Mol. Ecol. 7:381-397.

31. Templeton, A. R., Boerwinkle, E., and Sing, C. F. 1987. A cladistic 
analysis of phenotypic associations with haplotypes inferred from restriction endonuclease mapping. I. Basic theory and an analysis of alcohol dehydrogenase activity in Drosophila. Genetics 117:343-351.

32. Templeton, A. R., and Sing, C. F. 1993. A cladistic analysis of phenotypic associations with haplotypes inferred from restriction endonuclease mapping. IV. Nested analyses with cladogram uncertainty and recombi- nation. Genetics 134:659-669.

33. Valleau, W. D., Fergus, E. N., and Henson, L. 1933. Resistance of red clovers to Sclerotinia trifoliorum Erik. and infection studies. KY. Agric. Exp. Stn. Bull. 341:113-131.

34. Wolf, F. A., and Cromwell, R. O. 1919. Clover stem rot. N.C. Agric. Exp. Stn. Tech. Bull. 16. 